traders and whalers, but lawlessness, arising from "the absence of necessary laws and institutions", led, a hundred years ago, to bringing tho islands under the sovereignty of the Queen of England. It is the centenary of this event which New Zealand began to celebrate last week when a great exhibition was opened at Wellington. It is fitting in a new country that prominence should be given to the natural resources of the country, forests, farm lands, and minerals, and to the means which havo led to their exploitation, of which the development of methods of transport has been pro-eminent. Two thirds of New Zealand's land is now 'occupied', for the most part not by great landowners but by persons holding less than 320 acres. It is these European settlers who have developed the resources of their country in such a way as to minimize the disadvantages of isolation from the great consuming centres of the world. Happily the economic exploitation of the country has not been accompanied by a disappearance of the native people, for the sixty thousand Maoris live in friendly co-operation with the Europeans and enjoy full social and political equality. This successful oxperiment in Statebuilding will be worthily celebrated in New Zealand throughout the coming year, and it must be a matter of regret that the war, which has, once again, brought out the loyalty of the Dominion, should have pre. vented more active participation in this event by citizens from other parts of the British Commonwealth.

\section{Politics and Academic Qualifications in Germany}

RESTRICTIONS on academic freedom in Germany, already sufficiently stringent, are to cut more deeply still into the roots of intellectual development. According to the Berlin correspondent of a Copenhagen nowspaper, quoted in The Times of November 13, the German censorship will see in future all scientific works written for doctors' degrees. This, it is said, is intended to guard against the introduction of theories offending against Nazi doctrines in polities, law, literature, and the population policy. In view of the distorted interpretation of certain scientific and historical facts which alono is acceptable officially in Germany to-day, it might be thought that any further bar to research or freedom of thought would scarcely bo necessary to render any approach to originality innocuous. In order, however, to ensuro that orthodoxy, or at least what is regarded as such, shall prevail over any attempt at $\mathfrak{a}$ scientific and dispassionate examination of fact, which might lead to conclusions at odds with officially approved conclusions, decision as to the fate of any given thesis will not rest with an academic body, which at least might bo expected to bring a trained and instructed intelligence to the examination of the bearing of an argument and the value of its evidence, but with the censorship. No thesis will even be submitted for scientific examination until it has passed the censor. Regimentation thus strikes at the very root of intellectual development and scientific training. These must no longer be concerned with the search for truth in the investigation of the facts of Nature and history in both the broad and narrower sense, but only with the fanatical application of a selective theory dictated by political prejudice.

\section{Horrocks's Observation of the Transit of Venus}

Three hundred years ago on Sunday, November 24 (O.S.), 1639, the young Lancashire curato Jeremiah Horrocks, and his friend William Crabtree, the one at Hoole, near Preston, and the other at Broughton, near Manchester, observed tho transit of Venus across the sun's disk, and thus, as Robert Grant said, "did two young men cultivating astronomy together in a state of almost complete seclusion in one of the northern counties of. England enjoy the privilege of witnessing a phenomenon which human oyes had never before beheld and which no ono was destined again to see until inore than a hundred years had passed away". At Broughton tho sky had been over. cast most of the day, but fortunately cleared just in time for Crabtree to see tho transit. At Hoole, Horrocks had watched from sunrise until his duties called him to church. At 3.15 p.m., when again free, he resumed his observations, when, as ho wrote, "Oh most gratifying spectaclo! tho object of so many earnest wishes, I perceived a new spot of unusual magnitude, and of perfectly round form, that had just wholly entered upon the left limb of the sun, so that the margins of the sun and the spot coincided with each other, forming the angle of contact." Owing to the approach of sunset, ho was unable to observe the planet longer than half an hour, but during this period he measured its distance from the sun three times. His younger brother Jonas at Liverpool was prevented from seeing the transit on account of cloud.

Horrocks, in 1639 , was about twenty-two years of age. The son of a farmer, he was born at Toxteth Park, Liverpool, and was taught the classics by a country schoolmaster. He was already "a very curious astronomer" when on May 15, 1632, ho entered Emmanuel College, Cambridge, as a sizar. Three years later ho left the University without taking a degree, but at home he again began his astronomical observation. Through the antiquary Christopher Towneley (1601-74) he began to correspond with Crabtree, his senior by about seven years, and they becamo fast friends. At the suggestion of Crabtree, Horrocks abandoned the study of Lansberg for that of Kepler, and set about revising the Rudolphine 'Tables. Early in 1639 he becamo curate at Hoole, and there made his calculations regarding Venus. Having set down his observations in a manuscript entitled "Venus in Sole Visa", ho resolved to visit Crabtree. Three letters dated October 3, December 12 and 19,1610 , referred to this intended visit, and it was on the back of the last that Crabtree wrote that his friend had died on January 3, 1641, being the very day previous to that he had planned for the visit. Crabtree appears to have survived him a very short time. Owing to the Civil War, the name of Horrocks was for the time completely fou gotten, but his manu- 